Jurnal Ilmiah Sport Coaching and Education Vol. 4 Juli 2020

\title{
PENGEMBANGAN KARAKTER DISIPLIN MELALUI SEPAKBOLA USIA DINI PADA LIGA INDONESIAN JUNIOR SOCCER LEAGUE 2018
}

\author{
Dhika Aristandi ${ }^{1}$ \\ Juriana $^{2}$ dan Hendro Wardoyo ${ }^{3}$ \\ Fakultas Ilmu Olahraga Universitas Negeri Jakarta \\ $\underline{\text { dhikaaristandi@gmail.com }}^{1}$, juriana@unj.ac.id $^{2}, \underline{\text { hwardoyo@unj.ac.id }}^{3}$
}

\begin{abstract}
ABSTRAK
Penelitian ini bertujuan untuk mengetahui sejauh mana pengembangan karakter disiplin melalui sepakbola usia dini pada peserta Indonesian Junior Soccer League 2018. Metode yang digunakan pada penelitian ini adalah metode survei, yaitu dengan menggunakan kuesioner pembentukan karakter disiplin. Teknik pengambilan sampel dalam penelitian ini adalah incidental sampling, yaitu yang dijadikan sampel adalah orang tua atau wali dari peserta liga Indonesian Junior Soccer League yang peneliti temui secara kebetulan sebanyak 368 orang. Penelitian ini merupakan penelitian deskriptif kuantitatif. Instrumen yang digunakan adalah angket. Instrumen yang telah tersusun tersebut dikonsultasikan kepada ahli, selanjutnya dilakukan uji validitas dengan hasil r-tabel 0,254 dan r-total 28,93 dan reliabilitas sebesar 0,85. Teknik analisis data yang dilakukan adalah analisis deskriptif dengan prosentase. Hasil penelitian menunjukkan bahwa pengembangan karakter disiplin melalui sepakbola usia dini pada peserta Indonesian Junior Soccer League 2018 adalah sebagai berikut : sebanyak 148 orang tua (40\%) menyatakan bahwa melalui sepakbola karakter disiplin anak sangat berkembang, sebanyak 121 orang (31\%) cukup berkembang, dan 99 orang (27\%) kurang berkembang terhadap pembentukan karakter disiplin anak melalui sepakbola.
\end{abstract}

Kata kunci: Pengembangan Karakter, Disiplin, Sepakbola Usia dini

\begin{abstract}
This study aims to find out how far the development of the character of discipline through early soccer in the league of Indonesian Junior Soccer League 2018. The method used in this research is survey method, that is by using questionnaire forming character of cooperation. The sampling technique in this research is incidental sampling, which is taken as sample is the parent or guardian of the Indonesian league participants Junior Soccer League who researchers meet by chance as much as 368 people. This research is quantitative descriptive. The instrument used is a questionnaire. Instrument that has been arranged was consulted to the expert, then tested the validity with the result rtabel 0,254 and rtotal 28,93 and reliability equal to 0,85 . Data analysis technique is descriptive analysis with percentage. The results showed that the development of the character of discipline through early soccer in the league Indonesian Junior Soccer League 2018 is in the category of low or bad as many as 148 people (40\%) on the formation of discipline character, as many as 121 people (31\%) have knowledge of being or enough to form the character of discipline, as many as 99 people $(27 \%)$
\end{abstract}

Abstrak Keywords: Character Development, discipline, Soccer Grassroot 


\section{PENDAHULUAN}

Sepakbola merupakan cabang olahraga yang sangat populer hampir di seluruh belahan dunia, demikian juga di Indonesia. Sepakbola merupakan salah satu cabang olahraga yang paling digemari masyarakat, terbukti banyak bermunculan klub-klub sepakbola di berbagai usia yang tentunya harus dilakukan pembinaan secara terusmenerus. Pembinaan sepakbola sejak usia dini harus dilakukan guna menciptakan bibitbibit pemain profesional di masa depan.

Keberadaan klub-klub dan sekolah sepakbola (SSB) sekarang ini semakin terasa manfaatnya. Bukan sekedar untuk mencapai prestasi tinggi dalam cabang olahraga sepakbola, namun sepakbola juga bermanfaat untuk memupuk sifat-sifat kejiwaan atau bakat yang positif. Bakat merupakan kumpulan sifat-sifat dan kemampuankemampuan yang memungkinkan seseorang mencapai prestasi tinggi. Bakat atlet yang satu tidak sama dengan bakat atlet yang lain apabila ditinjau dari tiap-tiap komponen kemampuan yang dimiliki. Oleh karena itu perlu pendekatan individual sehingga diketahui kelemahan dan kelebihan tiap-tiap atlet. Namun dalam sepakbola, salah satu sifat yang terpenting yang harus dimiliki dalam diri atlet adalah jiwa yang patuh dan menaati peraturan atau karakter disiplin.

Karakter disiplin merupakan salah satu karakter yang dapat ditanamkan pada atlet sebagai salah satu sikap dalam latihan. Karakter yang dibawakan oleh seorang individu mencerminkan kepribadian dari individu tersebut. Disiplin menunjukkan perilaku tertib, patuh pada berbagai ketentuan dan peraturan. Karakter disiplin juga mencerminkan sikap yang terlatih, patuh dan menaati peraturan. Dalam permainan sepakbola, pemain yang disiplin lebih disenangi seorang pelatih, sebab pemain dengan karakter tersebut dapat menguntungkan tim. Pemain yang disiplin dapat menjalankan taktik dan strategi yang diarahkan pelatih. Karakter disiplin sangat dibutuhkan untuk memenangkan pertandingan. Karakter disiplin harus dikembangkan pada atlet usia dini agar kepribadian mereka bisa berkembang sejalan dengan meningkatnya kemampuan bermain sepakbola.

Kebanyakan pengembangan sepakbola usia dini lebih kepada kemampuan teknis ketimbang membentuk karakter dasar dalam diri pemain. Padahal, usia dini adalah usia paling krusial karena merupakan masa dimana banyak menyerap ilmu dari siapapun. Oleh karena itu, pengembangan karakter disiplin ini harus benar-benar dibimbing dengan baik. Melalui latihan-latihan, semestinya karakter disiplin juga bisa terbentuk.

Pertandingan untuk kategori anak usia dini di Indonesia cukup marak diselenggarakan. Misalnya pada gelaran Indonesian Junior Socccer League (IJSL) yang tiap tahun selalu menjadi wadah buat anak-anak usia dini. Indonesian Junior Soccer League ini merupakan salah satu kompetisi usia dini yang bergulir secara berkelanjutan sejak tahun 2013 sudah memasuki tahun ke-6 pada tahun 2018 ini. Kompetisi yang diikuti oleh 48 tim dari berbagai SSB ini dibagi menjadi tiga grup yaitu, 16 tim grup merah, 16 tim grup biru dan 16 tim grup putih yang akan bertanding dalam sistem setengah kompetisi. Peringkat 1-4 disetiap grup berhak mengikuti putaran kedua. Kompetisi ini terfokus pada penyaluran dan pengembangan potensi minat dan bakat anak, mengukur dan mengevaluasi kemampuan selama berlatih, menanamkan jiwa sportifitas dan bersosialisasi, memproteksi diri dari pergaulan yang bersifat negatif serta membentuk karakter anak.

Karakter untuk anak usia dini sangatlah penting karena dalam pertandingan anakanak diharuskan untuk bermain sportif, tidak egois, disiplin dan jujur. Menurut Eri Sudewo ada tiga pondasi dasar yang menjadikan seseorang bisa mengontrol dirinya untuk menjadi orang baik yaitu tidak egois, jujur dan disiplin.

Sehubungan dengan uraian tentang karakter disiplin dalam anak usia dini, peneliti tertarik untuk melaksanakan 
penelitian tentang pengembangan karakter disiplin melalui sepakbola pada anak usia dini.

Karakter merupakan perilaku baik dalam menjalankan peran sesuai amanah dan tanggung jawab. Selain itu menurut Kamus Besar Bahasa Indonesia karakter adalah sifatsifat kejiwaan, akhlak atau budi pekerti yang membedakan seseorang dengan yang lain.

Selain hal-hal yang disebutkan diatas, dalam pembentukan kualitas manusia, peran karakter tidak dapat disisihkan. Karakter inilah yang menempatkan baik tidaknya seseorang. Posisi karakter bukan sebagai pendamping kompetensi melainkan menjadi dasar, dan tanpa karakter peningkatan diri berjalan tanpa rambu dan aturan. Pembentukan karakter dapat dilakukan sejak dini melalui pendidikan, baik yang diselenggarakan oleh lembaga-lembaga non formal lainnya, yang diharapkan mampu mencetak generasi yang tangguh serta berkarakter, hal tersebut tentu tak lepas dari karakter dasar yang dibentuk sejak usia dini.

Menurut Sudewo karakter dasar terdiri dari 3 dimana menjadi sifat dasar manusia diantaranya, kerjasama, jujur dan disiplin. Penjelasan kutipan di atas sebagai berikut :

1. Kerjasama adalah suatu usaha bersama antara orang perorangan atau kelompok manusia untuk mencapai satu atau beberapa tujuan bersama. Selain itu kerjasama juga sebagai suatu usaha antara orang perorangan atau kelompok manusia diantara kedua belah pihak untuk tujuan bersama sehingga mendapatkan hasil yang lebih cepat dan lebih baik. Kerjasama dimaksudkan sebagai suatu usaha bersama antara orang perorang atau kelompok manusia untuk mencapai satu tujuan bersama.

2. Jujur adalah kemampuan menyampaikan kebenaran, mengakui kesalahan, dapat dipercaya, dan bertindak secara hormat. Jujur harus ditanamkan pada anak agar dapat tumbuh menjadi pribadi yang dapat dipercaya dalam perkataan, perbuatan (tindakan) dan pekerjaan terhadap diri sendiri maupun orang lain, baik itu di rumah, di sekolah maupun di masyarakat.

3. Disiplin adalah suatu sikap, perbuatan untuk selalu mentaati peraturan. Kata disiplin berasal dari bahasa latin discipulus yang berarti "pembelajaran". Jadi disiplin berfokuskan pada situasi pengajaran. Menurut Ariesandi arti disiplin sesungguhnya adalah proses melatih pikiran dan karakter anak secara bertahap sehingga menjadi seseorang yang memiliki kontrol diri dan berguna bagi masyarakat.

The Liang Gie dalam Dictionary of Education mengartikan disiplin suatu keadaan dimana sesuatu itu berada dalam keadaan tertib, teratur dan semestinya, serta ada suatu pelanggaran-pelanggaran baik secara langsung maupun tidak langsung. Pengertian disiplin juga tergantung pada dua faktor yaitu waktu dan kegiatan atau perbuatan. Dalam pendidikan usia dini disiplin mempunyai peran yang penting, karena dalam kehidupan berorganisasi ada aturan yang perlu dijalankan. Karakter disiplin dapat menciptakan atlet atau manusia yang berkualitas.

Dalam hal ini terdapat pengertian lain mengenai disiplin. Disiplin adalah kunci utama menuju kesuksesan salah satunya menuju penghargaan diri, dan kebanggaan pribadi. Penjelasan tersebut merupakan pengertian disiplin dari berbagai para ahli yang pada maknanya memiliki kesamaan pada tercapainya tujuan.

Dalam membangun bibit atlet yang berkualitas, disiplin dimulai dari pendidikannya yang berkualitas dan dari para pengajarnya (pelatih) yang professional dalam melatih. Kedisiplinan harus di terapkan pada setiap klub agar nantinya setiap atlet memiliki tanggung jawab besar sebagai seorang atlet professional.

Kedisiplinan adalah modal utama untuk meraih kesuksesan. Dengan disiplin seseorang akan terbiasa dengan hal-hal yang membuat dirinya bisa berkembang, mengerjakan sesuatu tepat pada waktunya 
dan mengembangkan potensi yang ada pada dirinya.

Kedisiplinan menjadi alat yang ampuh dalam mendidik karakter. Keberhasilan seorang atlit terlihat dari kedisiplinan di setiap sesi latihan, penanaman atau penegakan disiplin dari seorang pelatih dapat dilakukan dengan beberapa cara sebagai berikut

1) Penuh motivasi

Erie Sudewo mendefinisikan penuh motivasi sebagai pendorong di dalam individu yang berpengaruh atas tingkat, arah, dan gigihnya upaya seseorang dalam suatu tujuan. Motivasi merupakan latar belakang yang menggerakan atau mendorong orang untuk melakukan sesuatu. Ada dua jenis motivasi, yaitu motivasi eksentrik adalah motivasi yang berasal dari luar dan motivasi intrinsik adalah motivasi yang berasal dari dalam diri kita.

2) Bersikap mandiri

Bersikap mandiri menurut Erie Sudewo adalah suatu kondisi dimana seseorang tidak tergantung pada orang lain dalam menentukan keputusan dan adanya sikap percaya diri. Bersikap mandiri adalah usaha seseorang untuk melepaskan diri dari orangtua untuk menggerakan sesuatu atas dorongan diri sendiri dan kepercayaan diri sendiri tanpa adanya pengaruh dari lingkungan dan ketergantungan pada orang lain. Inisiatif tercipta dari keberanian seseorang dalam mengambil keputusan dan pemikiran yang matang dan terencana. Dalam sepakbola pengambilan keputusan di butuhkan disaat dia ada bola ataupun tidak ada bola, kemandirian seorang untuk mengambil inisiatif sangat dibutuhkan dalam sepakbola.

3) Komitmen dan Konsisten

Komitmen dan konsisten menurut Erie Sudewo merupakan suatu keadaan individu dimana individu menjadi terikat oleh tindakannya. Pendidikan dan latihan merupakan salah satu faktor penting dalam membentuk dan menempa komitmen dan konsisten. Pendidikan dan latihan merupakan suatu proses yang di dalamnya ada beberapa aturan atau prosedur yang harus diikuti oleh peserta didik atau atlet. Misalnya seperti mentaati peraturan yang telah diberikan sebuah klub, menjalankan instruksi strategi yang diberikan pelatih pada saat latihan, menumbuhkan rasa setia kawan, kerja sama yang erat dan sebagainya. Sementara itu komitmen dan konsisten biasanya dikaitkan penerapan aturan, idealnya dalam menegakan aturan hendaknya diarahkan pada "takut akan aturan, bukan takut kepada orang". Jika hal ini tumbuh menjadi suatu kesadaran maka menciptakan kondisi yang cenderung berprestasi.

Selain itu untuk mencapai sebuah prestasi yang menjadi tujuan dibutuhkan tradisi disiplin yang kuat. Untuk membangun tradisi disiplin yang baik ada beberapa hal yang perlu dilakukan diantaranya adalah :

- Mengingat manfaat dan kerugiannya

- Mengingat cita-cita

- Memiliki tanggung jawab

- Pandai mengatur waktu.

Selalu mengingat manfaat besar disiplin akan mendorong seseorang untuk disiplin. Sebagai atlet dan pelatih sangatlah penting untuk mencapai sebuah prestasi. Citacita yang besar selalu membutuhkan kerja keras, semangat pantang menyerah dan prinsip maju tanpa mengenal mundur. Untuk menggapai semua itu butuh kedisiplinan. Cita-cita besar tidak akan terwujud kalau seseorang tidak disiplin melakukan pekerjaan yang berpengaruh besar dalam hidupnya.

\section{METODE}

Metode penelitian yang digunakan dalam penelitian ini adalah metode deskriptif dengan teknik survei, yaitu dengan menggunakan kuesioner yang berbentuk angket.Penelitian ini bertujuan untuk mengetahui pengembangan karakter disiplin melalui sepakbola usia dini pada peserta Liga 
Indonesia Junior Soccer League 2018. Teknik pengambilan sampel dalam penelitian ini adalah dengan menggunakan teknik Sampling Incidental. Teknik penentuan sampel ini berdasarkan kebetulan, yaitu siapa saja yang secara kebetulan/incidental bertemu dengan peneliti dapat digunakan sebagai sampel, bila dipandang orang yang kebetulan ditemui itu cocok sebagai sumber data. Secara kebetulan peneliti disana menemukan 368 orang tua peserta Indonesian Junior Soccer League yang cocok sebagai sumber data untuk penelitian.

\section{HASIL DAN PEMBAHASAN}

Penelitian ini bertujuan untuk mengetahui bagaimana pengembangan karakter disiplin melalui sepakbola usia dini pada peserta Indonesia Junior Soccer League. Data yang digunakan untuk mengidentifikasi pengembanga karakter disiplin melalui sepakbola usia dini yang diungkapkan melalui angket yang terdiri dari 15 pernyataan dan terbagi dalam tiga aspek yaitu penuh motivasi, bersikap mandiri, komitmen dan konsisten. Aspek penuh motivasi terdiri dari 5 pernyataan, aspek bersikap mandiri terdiri dari 5 pernyataan, sedangkan aspek komitmen dan konsisten terdiri dari 5 pernyataan.

Tabel 1. Pengembangan Aspek Penuh

\begin{tabular}{cccc}
\multicolumn{4}{c}{ Motivasi } \\
\hline No & Kategori & Nilai & Prosentase \\
\hline 1 & $\begin{array}{c}\text { Sangat } \\
\text { Berkembang }\end{array}$ & $\begin{array}{c}20- \\
25\end{array}$ & $48 \%$ \\
\hline 2 & $\begin{array}{c}\text { Cukup } \\
\text { Berkembang }\end{array}$ & $\begin{array}{c}14- \\
19\end{array}$ & $33 \%$ \\
\hline 3 & $\begin{array}{c}\text { Kurang } \\
\text { Berkembang }\end{array}$ & $8-13$ & $19 \%$ \\
\hline \multicolumn{4}{c}{ Total } \\
\hline
\end{tabular}

Hasil penelitian menunjukkan bahwa aspek penuh motivasi pada peserta Indonesian Junior Soccer League sangat berkembang dengan prosentase $48 \%$, cukup berkembang $33 \%$ dan kurang berkembang $19 \%$.

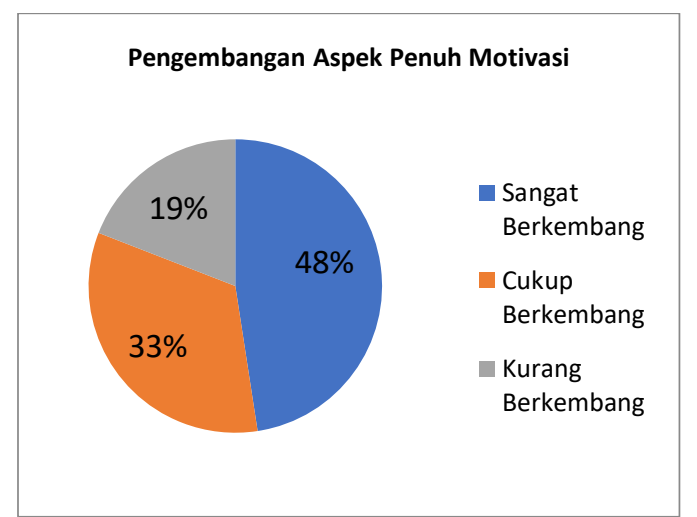

Gambar 1. Diagram pengembangan aspek penuh motivasi

Sementara itu hasil penelitian aspek bersikap mandiri terdiri dari 5 pernyataan, 4 pernyataan positif dan 1 pernyataan negatif. 4 pernyataan positif terdiri dari nomor $2,5,9$, dan 13 sedangkan untuk 1 pernyataan negatif terdiri dari nomor 11 .

Tabel 2. Pengembangan Aspek Bersikap Mandiri

\begin{tabular}{cccc}
\hline No & Kategori & Nilai & Prosentase \\
\hline 1 & $\begin{array}{c}\text { Sangat } \\
\text { Berkembang }\end{array}$ & $22-25$ & $41 \%$ \\
\hline 2 & $\begin{array}{c}\text { Cukup } \\
\text { Berkembang }\end{array}$ & $18-21$ & $33 \%$ \\
\hline 3 & $\begin{array}{c}\text { Kurang } \\
\text { Berkembang }\end{array}$ & $14-17$ & $26 \%$ \\
\hline \multicolumn{3}{c}{ Total } & $100 \%$ \\
\hline
\end{tabular}

Hasil penelitian di atas menunjukkan bahwa aspek bersikap mandiri pada peserta Indonesian Junior Soccer League sangat berkembang dengan prosentase $41 \%$, cukup berkembang $33 \%$ dan kurang berkembang $26 \%$.

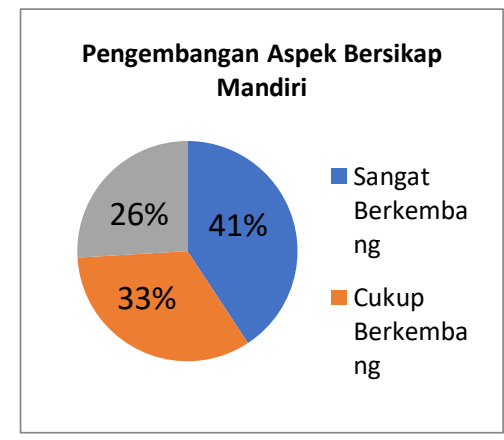

Gambar 2. Diagram Pengembangan Aspek Bersikap Mandiri 
Dan hasil penelitian lain menunjukkan bahwa aspek komitmen dan konsisten terdiri dari 5 pernyataan, 4 pernyataan positif dan 1 pernyataan negatif. 4 pernyataan positif pada nomor $4,7,8$ dan 14 , sedangkan untuk 1 pernyataan negatif pada nomor 3 .

Tabel 3. Pengembangan Aspek Komitmen dan Konsisten

\begin{tabular}{cccc}
\hline No & Kategori & Nilai & Prosentase \\
\hline 1 & $\begin{array}{c}\text { Sangat } \\
\text { Berkembang }\end{array}$ & $22-25$ & $40 \%$ \\
\hline 2 & $\begin{array}{c}\text { Cukup } \\
\text { Berkembang }\end{array}$ & $18-21$ & $33 \%$ \\
\hline 3 & $\begin{array}{c}\text { Kurang } \\
\text { Berkembang } \\
\text { Total }\end{array}$ & $15-17$ & $27 \%$ \\
\hline \multicolumn{3}{c}{} & $100 \%$ \\
\hline
\end{tabular}

Hasil penelitian menunjukkan bahwa aspek komitmen dan konsisten pada peserta Indonesian Junior Soccer League sangat berkembang dengan prosentase $40 \%$, cukup berkembang $33 \%$ dan kurang berkembang $27 \%$.

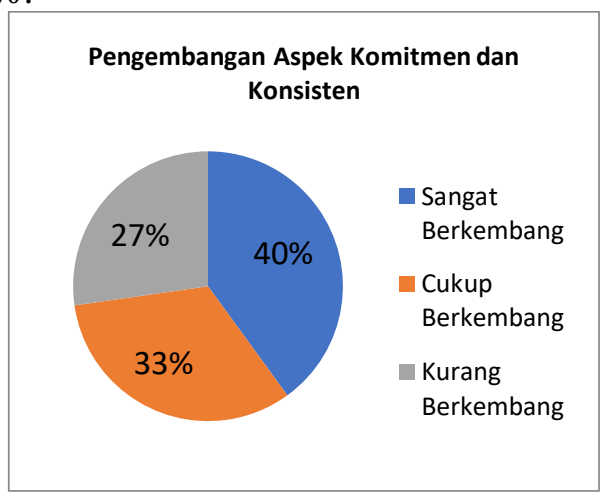

Gambar 3. Diagram Pengembangan Aspek

Komitmen dan Konsisten

\section{PEMBAHASAN}

Berikut ini gambaran tentang data penelitian yang terdiri dari pengkategorian hubungan pembentukan karakter disiplin dengan sepakbola usia Dini pada Liga Indonesia Junior Soccer League berikut ini adalah hasil deskripsi data hasil penelitian :
Tabel 4. Pengembangan Seluruh Aspek Dari Karakter Disiplin

\begin{tabular}{|c|c|c|c|c|}
\hline $\begin{array}{l}\mathrm{N} \\
\mathrm{O}\end{array}$ & Kategori & $\begin{array}{c}\text { Nila } \\
\text { i }\end{array}$ & $\begin{array}{l}\text { Frekuen } \\
\text { si }\end{array}$ & $\begin{array}{c}\text { Prosenta } \\
\text { se }\end{array}$ \\
\hline 1 & $\begin{array}{c}\text { Sangat } \\
\text { Berkemba } \\
\text { ng }\end{array}$ & $\begin{array}{l}65- \\
75\end{array}$ & 148 & $40 \%$ \\
\hline 2 & $\begin{array}{c}\text { Cukup } \\
\text { Berkemba } \\
\text { ng }\end{array}$ & $\begin{array}{l}55- \\
64\end{array}$ & 121 & $33 \%$ \\
\hline 3 & $\begin{array}{c}\text { Kurang } \\
\text { Berkemba } \\
\text { ng }\end{array}$ & $\begin{array}{l}45- \\
54\end{array}$ & 99 & $27 \%$ \\
\hline & Total & & 368 & $100 \%$ \\
\hline
\end{tabular}

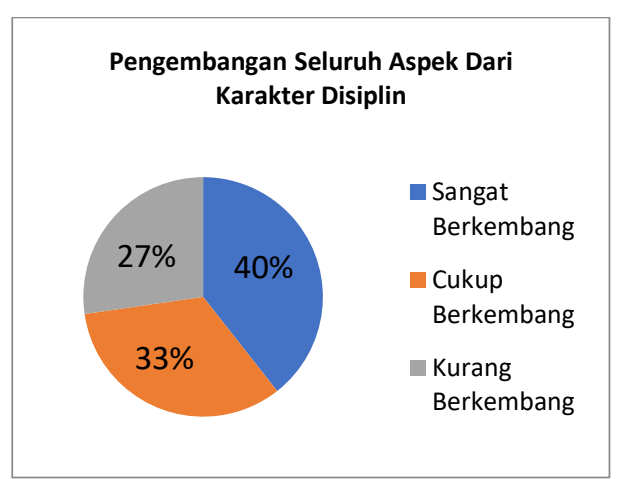

Gambar 4. Diagram Pengembangan Seluruh Aspek Dari Karakter Disiplin

Bagian ini akan menjelaskan lebih lanjut mengenai hasil analisis data yang telah dilakukan serta kaitannya dengan permasalahan dan tujuan penelitian. Tujuan dari penelitian ini adalah untuk mengetahui pembentukan karakter disiplin melalui sepakbola usia dini pada peserta Indonesia Junior Soccer League 2018. Hasil analisis deskriptif menunjukkan bahwa pembentukan karakter disiplin yang diperoleh melalui sepakbola usia dini pada peserta Indonesia Junior Soccer League 2018 sebagian besar berada pada kategori sangat berkembang. Hal ini terlihat dari data-data yang menunjukkan $148(40 \%)$ orangtua menyatakan bahwa dari sepakbola karakter disiplin anak sangat berkembang, sebanyak 121 orang (33\%) cukup berkembang, sebanyak 99 orang $(27 \%)$ kurang berkembang. 


\section{KESIMPULAN}

Berdasarkan hasil keseluruhan, diketahui bahwa pembentukan karakter disiplin melalui sepakbola usia dini pada peserta Indonesia Junior Soccer League 2018 sebagian besar orangtua menyatakan sangat berkembang. 148 atau (40\%), sementara sisanya yaitu : sebanyak 121 orang (33\%) cukup berkembang, sebanyak 99 orang $(27 \%)$ kurang berkembang

\section{SARAN}

Berdasarkan pembahasan hasil penelitian dan kesimpulan yang telah dipaparkan, bagi pihak orangtua maka disampaikan saran-saran sebagai berikut:

1. Sebagai informasi perkembangan karakter disiplin anak

2. Peserta didik mampu memahami pentingnya pengaplikasian disiplin dalam sepakbola.

3. Mensosialisasikan kepada Orangtua bahwa Sekolah Sepakbola (SSB) bisa membentuk karakter disiplin melalui sepakbola.

Sementara itu bagi pihak pelatih sekolah sepakbola (SSB) maka disampaikan saran-saran sebagai berikut :

1. Untuk memberikan pengetahuan tentang pengembangan karakter disiplin dalam pembinaan usia muda

2. Untuk terus mengembangkan karakter disiplin peserta didik melalui sepakbola

3. Meningkatkan prestasi melalui pengembangan karakter disiplin pada pembinaan usia muda.

\section{DAFTAR PUSTAKA}

Ali Imron, Manajemen Peserta Didik (Jakarta : PT Gramedia Pustaka Utama, 2008)

Ariesandi, Rahasia Mendidik Anak Agar Sukses dan Bahagia, Tips dan Terpuji Melejitkan Potensi Anak (Jakarta : PT Gramedia Pustaka Utama, 2008)

Asmani, Tips Menjadi Guru Inspiratif, Kreatif, Inovatif (Yogyakarta : DIVA Press, 2010)

Endang Purwoastuti dan Elisabeth Siwi Walyani, Metodologi Penelitian (Yogyakarta : PT Pustaka Baru, 2014)

Erie Sudewo, Character Building (Jakarta : PT Gramedia 2011)

FIFA, Grassroots (Jakarta : Pertamina Cerdas, 2014)

Kaswan, Leadership and Teamworking (Bandung : Alfabeta, 2013)

Luxbacher Josep, Sepakbola Taktik dan Teknik Bermain (Jakarta : PT Raja Grafindo Persada, 1997)

Sugiyono, Metode Penelitian kuantitatif, kualitatif dan R\&D (Bandung : Alfabeta, 2011) 